\title{
METHODOLOGICAL ASPECTS OF RATIONAL DESIGN FORMATION OF INFRASTRUCTURE OF AGRARIAN SECTOR OF UKRAINE
}

\author{
Ivan KORCHYNSKYY', \\ Lviv National Agrarian University, Ukraine
}

\begin{abstract}
Methodological aspects of formation of rational design of infrastructure of agrarian sector of Ukraine on the basis of the institutional approach and laws of architectonics are examined. It is shown that the agrarian sector of Ukraine is a complex socio-economic system, the formation and development of which is in the process of market transformation what is caused by institutional influences. In general the process of relations institutionalization imply their formalization and standardization, in other case the subject of public life could not predict the actions of other entities associated with him and ensure their cooperation. One of the specific characteristic of human society is formed institutional system that regulates behaviour. In the article the factors of influence on the conduct of being in charge subjects are considered in the conditions of development of market economy. The special attention is spared the institutional factors of the economy growing. Methodology. The meaning of "agricultural field" and "infrastructure" and their mutual consistency is classified. As the scientific method, the institutional approach of principles of architectonics has been used, which allowed to justify the creation of a rational approach to the design of infrastructure in agrarian sector as a whole on the basis, relation and interdependence of its elements, based on the fundamental laws of architectonics (law of equilibrium, law of the golden mean structuring). The article demonstrates a necessary of the choice of a theory of institutionalism as the main methodological basis for the study of the process of innovation development of economic system of Ukraine. It is determined that the inefficient activities of institutions in Ukraine are the main cause of the low level of innovation, which has a negative impact on the development of the economy as a whole. Results. Research points on new aspects of infrastructure as a part of the entire socio-economic system that implements the functions in the agricultural sector and significant effect on the effective functioning of the system. Value/originality. The different organizational and functional classifications of institutions that proposed by well-known western and natives authors are analyzed in this article. Also the basic prerequisites of forming institutions are considered here. According to the famous western approaches to the institutional effectiveness the author tried to analyses main social, economical and political factors that influence the institutional building.
\end{abstract}

Key words: agriculture, infrastructure, architectonics, characteristic of human society significant effect institutional effectiveness.

JEL Classification: O01, O04, Q13, B15, A11, A14

\section{Introduction}

The agricultural sector of Ukraine is a complex social and economic system. In the process of market transformation the formation and development it is influenced by the institutional factors. In most cases these factors were not the consequence of advanced scientific researches and deliberate actions and but the result of random and unsystematic decisions of the governing bodies which they carry out by realizing their mercantile business or lobbying interests. In developed countries the agricultural sector as the system evolved in an evolutionary way. That is why, it is a product of a market system, where all the interests are sufficiently balanced and harmonized because this

Corresponding author:

${ }^{1}$ Department of Economic Theory, Lviv National Agrarian University.

E-mail: Ivan_Korchynskyy@mail.ru process has been taking for a long time. Current Ukrainian economic system is the result of transformation process, where balance and harmony as qualitative characteristics of the system at an early stage of their development. In this regard, institutional, organizational and legal framework of agricultural sector infrastructure as part of the economic system of the state still has imperfect design and lack of action effectiveness. It creates problems for all infrastructure functioning and distorts its impact on effectiveness of the agricultural sphere in general. Architectonics of infrastructure significantly affects the level of transaction costs of the economic system, which was formed in the sphere of agriculture. This is necessary 
to take into account while reasoning of the economic system strategy development. It outlines the content of the complex scientific and economic problem which needs to be deeply investigated by theoretical and applied researches (Ostrom, 2012).

\section{Analysis of recent researches and publications}

Institutional aspects of economic systems formation and development, including agriculture, have been attracting much attention from scientists and government lately. It is worth mentioning the results of research and publications of A. Gritsenko, B. Valentine, M. Malik, Y. Lopatinskii (Lopatinskii, 2006), P. Sabluk, A. Nord, V. Yurchishin, V. Yakubenko and scientific developments of other scientists based on institutional theory in its various directions and trends, mainly covered in by D. North, W. Williamson (Williamson, 2002), R. Coase and others.

A significant contribution to the development of these theoretical approaches concerning transformation economies has been made by Russian scientists such as V. Kapelyushnikov, S. Nureyev, S. Kirdina and others. However, sectoral aspects of the implementation and application of those theoretical achievements in agriculture are insufficiently investigated. This situation takes place because problems of formation of the institutional framework of agrarian economy is extremely complex both in theoretical and applied value.

Today Ukrainian agricultural sciences have practically no deep researches concerning the process of the institutions formation which analyze agricultural infrastructure. As a rule, in Ukraine, these researches are limited to analysis of problems which take place in some markets (commodity, financial, consumer), and their infrastructure is seen as a separate element of these markets. Also, there is no approach in which infrastructure is perceived as an integrated shell of all socio-economic system, which includes agricultural sector as a whole, including its social manifestations (Pavlov, 2012).

\section{Setting objectives}

It is necessary to investigate the methodological aspects of infrastructure formation of Ukrainian agricultural sector, justifying the feasibility of institutional approach and its organic combination with the basic principles of architectonics as the scientific method. This will give an opportunity to justify a creation of a rational construction of agricultural sphere infrastructure as a whole, which is based on the principles of structuring, communication and interdependence of its elements.

A small number of publications on the above mentioned topic cannot recreate a full, sufficient and an objective picture of current scientific knowledge about the actual problems and that fact predetermined of the article writing (Kostyrko, 2014).

\section{Presenting the main material}

In order to outline clearly the object of scientific research, it is necessary to determine the content of individual concepts namely to specify understanding of concepts - "agricultural sphere" and "infrastructure", and their mutual consistency. Without going into the debate on the content, in our research agricultural sector is seen as comprehensive concept that incorporates all processes of human activity in rural area - as agroindustrial and social, across the breadth of its manifestation. In the context of this, agriculture economy is the primary concept, which expanded by servicing and processing industries to the agricultural sector of the economy. Agricultural sector together with the social infrastructure of the rural areas forms agricultural sphere. This approach is logically justified by V.I. Kurylo (Kurylo, 2014), and we accepted it as a basis in the process of investigation of infrastructure architectonics problems of a country's agricultural sector.

As to the concept of infrastructure, for research purposes we interpret its meaning as a whole set of institutes and institutions that form the perfect structure, which provides operating conditions of all subjects of the economic relations within the agricultural sphere and outside it, creating such level of transaction costs within the economic system, in which economic mechanism operates effectively.

In some publications we covered problems of market infrastructure formation in the agricultural sphere. But there are questions that were not answered (Berezivskyj, 2011, Ostashko, 2004). For example, very important practical problem is dominance of the intermediaries on the market, whose incomes are unreasonably high.

The banking sector concentrates its resources on large producers, limiting access to loans to other entities, farmers and small agribusiness. State regulation, tax and budget systems create such a redistribution mechanism of national income in which agricultural sector as an integrated socio-economic system is developing with significant deformations. The manifestation of such deformations is the growth of monopolization and concentration of all resources in large agricultural farms as well as continued growth of poverty of peasants and rural areas decline. There are also contradictions between the rates of individual components of all economic system, which was formed in the agricultural sector. The manufacturing sector is evolving with noticeable success, especially in the horticulture (the forefront of grain exports, sunflower). As for livestock, we can see that poultry is practically restored, pig farming is in line, a modern organizational structure is forming. In general, production efficiency is increasing and financial results are improving. However, the development of infrastructure significantly has been slowed, and this fact distorts all economic mechanism of agricultural sphere and creates imbalances in system of industry's revenues distribution. This indicates that the economic system, which was formed in the agricultural sector needs to move 
to a different trajectory of development which will based on a better overall balance and coherence between different its links in order to achieve such equilibrium state in which the interests of all economic process actors would be provided with income adequate to their place and role in this system. New challenges require new scientific researches, including theoretical and methodological approaches to their implementation. The end of 90s in XX century, the interest in institutionalism as the direction of modern economic thought and methodological basis for scientific research sharply increased. Among the authors of such researches the following authors are worth to be mentioned: Arhiyereyev S.I., V.V. Dementev, G.V. Zadorozhnyy, A.V. Nosova (Nosova, 2011) R.F. Pustoviyt, A.A. Tkach, A.A. Chukhno, O.L. Jaremenko and etc.

In Ukraine the publication of a number of fundamental works, including collective monograph "Institutional Architectonics and Dynamics of Economic Transformation" became a notable scientific event. This monograph was a result of team work of the Institute of Economics and Forecasting of NASU scientists, who started a new scientific direction - institutional architectonics (Grytsenko, 2004).

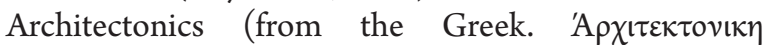
$(\tau \dot{\chi} \chi \nu \eta)$ - construction, construction) - is a concept which is used for expression of construction laws which are inherent for a constructive system of building; it is the basic principle of building design as a whole, integral relationship of its main parts, composition. In a broader sense architectonics is the basic principle of structuring, communication and interdependence of the elements. In economic theory architectonics combines knowledge of the deep institutional structure, building skills and general construction plan for an integrated system of institutions that form the new framework (architecture/ architectonics) of socio-economic systems and policy, particularly in agriculture.
Analysis of market reforms practice clearly indicates that institutional approaches to solving urgent theoretical and practical issues are used not enough in the state. Within this new research direction and on its methodological basis it is necessary to investigate and to solve a number of theoretical and practical problems that occur in the process of formation and operation of infrastructure as a separate component of the overall socio-economic system of the agricultural sphere.

Methodological basis of the research is based on the integrated application of the substantive provisions of institutional theory that are used as a scientific environment where architectonics laws are employed as a method of designing of an economic system with elements, which are harmoniously combined, creating an effective construction. Quality parameters of this construction allow achieving a better and more just social product distribution through equal effects that the separate elements of infrastructure and institutions of agricultural sphere receive.

Architectonics basic laws (the law of equilibrium, the law of the golden mean and law of structuring) are acting in all integral systems: natural, technological, biological and social.

The essence of the law of equilibrium, in particular, lies in the fact that all elements of the integrated system are moving toward peace regarding other elements or they are in this state. It means that all elements of agricultural sphere infrastructure should be changed and improved so that to approximate the entire system to the point of equilibrium for which it will function effectively, ensuring consistency of economic the interests of all the elements that constitute it.

The law of the golden mean provides dimentional and quantitative description of the agricultural sphere infrastructure through the interaction of its uniform elements as an integrated system that is in the constant

Table 1

Institutional factors affecting economic growth

\begin{tabular}{|c|c|}
\hline TERMS & Circumstances and the main actors (factors) \\
\hline General & $\begin{array}{l}\text { - dominant idea or thought in society } \\
\text { - historical development of society }\end{array}$ \\
\hline $\begin{array}{l}\text { Social and } \\
\text { psychological } \\
\text { characteristics }\end{array}$ & $\begin{array}{l}\text { - } \text { relatively stable society that change through evolution } \\
\text { - } \text { psychological traits of people living in the community } \\
\text { - } \quad \text { special role of national culture, mentality, ethnic types of behavior }\end{array}$ \\
\hline $\begin{array}{l}\text { Political } \\
\text { constitution }\end{array}$ & - quality and methods of cooperation between the state, business, political culture and informal rules and traditions \\
\hline Economic & $\begin{array}{l}\text { - clear «rules» that define effective and-effect activities } \\
\text { - clearly defined property rights. } \\
\text { - } \text { social functions and trading rules } \\
\text { - efficiency of the banking and financial systems } \\
\text { - appropriate methods of risk management and insurance system } \\
\text { - common tax system } \\
\text { - decentralized economic system }\end{array}$ \\
\hline
\end{tabular}

Source: Piech,K. (ed.), Economic Policy and Growth of Central and East European Countries. London,University College London, 2003, p. 8 
motion and integrate action of all items in the characteristic, which reproduces the integrity of the system relative to other systems through some average meaning. This law allows you to evaluate, for example, the average return (yield) of the individual segments of infrastructure and track its changes in space and time, which is important for analyzing the effectiveness of institutional changes in agricultural sphere.

The law of structuring describes the relationship of elements that have internal factors of and are able to unite in some holistic formation and to structure within the broader integrity, which is also important in the study of areas of agricultural sector infrastructure development and institutional design institutional changes process.

Investigation process of the formation and operation of agricultural sphere infrastructure is considered as an integral part (element) of all the socio-economic system of the state, which is considered from the standpoint of institutional theory. It is combined with approaches based on architectonics laws and enables deeper insight into the nature and character of the process as well as creates new criteria for its course.

A new development for the agricultural sector of Ukraine has an innovative infrastructure as a lot of companies and organizations, institutions, their associations, associations that provide services to ensure the innovation (finance, consulting, marketing, communicative information, legal, education and etc.). As you know, one hundred novice business success in business reach just twelve. The realities of the Ukrainian Agrarian the percentage is much lower. The instability of the political environment, crisis expectations for the economy in general, and particularly in the agricultural sector, the unpredictability of market conditions - all this hinders agricultural output Ukrainian sector of the protracted crisis. In this regard, it is important touse the method to survive from 30 to $80 \%$ businessmen-beginners (Zheleny, 2004). This component of the innovation infrastructure - Business incubators, which began to be created in Ukraine in 1997, but now considered a classic, only one - in the White Church. FirstBusiness Incubator (the word "incubator" means "growing"), appeared in late 50-ies in the United States. United under one the roof of the company shared experiences in dealing with similar problems, consult a lawyer and an economist, and thus significantly quickly overcome bureaucratic obstacles. Within a few years30\% of these beginners business moved from small business to the middle (Zheleny, 2004). Since then, the local US authority's began to sponsor the development of a business incubator that brought considerable benefitsfor power (new jobs, more taxes).

Creating a network of business centres and business incubators in the agrarian sector of Ukraine since the regional centres, enabling the provision of services such as secretarial, providing office equipment, teaching computer skills. It will give the possibility of obtaining preferential loans, business training planning, and so on. All of this is one of the most important aspects building infrastructure for the creation and development of small and mediumsized entrepreneurship in rural areas, and thus can play an important role in the revival of agricultural production in Ukraine.

It is precisely in this economic and social context that the modern problems of economic development must be considered. The fundamental issue can be stated succinctly. Successful development policy entails an understanding of the dynamics of economic change if the policies pursued are to have the desired consequences. And a dynamic model of economic change entails as an integral part of that model analysis of the polity since it is the polity that specifies and enforces the formal rules. We are still some distance from having such a model but the structure that is evolving in the new institutional economics, even though incomplete, suggests radically different development policies than those of either traditional development economists or orthodox neoclassic economists. Development economists have typically treated the state as either exogenous or as a benign actor in the development process. Neoclassical economists have implicitly assumed that institutions (economic as well as political) don't matter and that the static analysis embodied in allocative-efficiency models should be the guide to policy; that is "getting the prices right" by eliminating exchange and price controls. In fact the state can never be treated as an exogenous actor in development policy and getting the prices right only has the desired consequences when you already have in place a set of property rights and enforcement that will then produce the competitive market conditions. Before going further it is essential to distinguish clearly institutions from organizations. Institutions are the rules of the game of a society or more formally are the humanly-devised constraints that structure human interaction. They are composed of formal rules (statute law, common law, regulations), informal constraints (conventions, norms of behaviour, and self imposed codes of conduct), and the enforcement characteristics of both.

Organizations are the players: groups of individuals bound by a common purpose to achieve objectives. They include:

- political bodies (political parties, the senate, a city council, a regulatory agency);

- economic bodies (firms, trade unions, family farms, cooperatives);

- social bodies (churches, clubs, athletic associations);

- educational bodies (schools, colleges, vocational training centres).

These definitions under-gird five propositions that define the essential characteristics of institutional change:

1. The continuous interaction of institutions and organizations in the economic setting of scarcity and hence competition is the key to institutional change.

2. Competition forces organizations to continually invest in skills and knowledge to survive. The kinds of skills and knowledge individuals and their organizations acquire will 
shape evolving perceptions about opportunities and hence choices that will incrementally alter institutions.

3. The institutional framework dictates the kinds of skills and knowledge perceived to have the maximum pay-off.

4. Perceptions are derived from the mental constructs of the players.

5. The economies of scope, complementaries, and network externalities of an institutional matrix make institutional change overwhelmingly incremental and path dependent.

Elaborate on these propositions. Economic change is a ubiquitous, ongoing, incremental process that is a consequence of the choices individuals and entrepreneurs of organizations are making every day. While the vast majority of these decisions are routine (Nelson and Winter, 1982) some involve altering existing "contracts" between individuals and organizations. Sometimes that recontracting can be accomplished within the existing structure of property rights and political rules; but sometimes new contracting forms require an alteration in the rules. Usually existing informal norms of behavior will guide exchanges, but sometime such norms will gradually be modified or wither away. In both instances institutions are gradually being modified. Modifications occur because individuals perceive that they could do better by restructuring exchanges (political or economic). The source of the changed perceptions may be exogenous to the economy-for instance a change in the price or quality of a competitive product in another economy that alters the perceptions of entrepreneurs in the given economy about profitable opportunities. But the fundamental source of change is learning by entrepreneurs of organizations. While some learning is a result of idle curiosity, the rate of learning will reflect the intensity of competition amongst organizations. Competition is a ubiquitous consequence of scarcity and hence organizations in an economy will engage in learning to survive. But the degree can and does vary. If competition is muted as a result of monopoly power the incentive to learn will be reduced. The rate of learning determines the speed of economic change, the kind of learning determines the direction of economic change. The kind of learning is a function of the expected pay-offs of different kinds of knowledge and therefore will reflect the mental models of the players and most immediately at the margin, the incentive structure embodied in the institutional matrix. As noted earlier if the institutional matrix rewards piracy (or more generally redistributive activities) more than productive activity then learning will take the form of learning to be better pirates.

Change is typically incremental, reflecting ongoing ubiquitous evolving perceptions of the entrepreneurs of organizations in the context of an institutional matrix that is characterized by network externalities, complementaries and economies of scope among the existing organizations. Moreover since the organizations owe their existence to the institutional matrix, they will be an ongoing interest group to assure the perpetuation of that institutional structure thus assuring path dependence. Revolutions do occur, 7 however, when organizations with different interests emerge (typically as a result of dissatisfaction with the performance of existing organizations) and the fundamental conflict between organizations over institutional change cannot be mediated within the existing institutional framework.

It is one thing to describe the characteristics of economic change; it is something else to prescribe the correct medicine to improve the performance of economies. We simply don't know how to transform ailing economies into successful ones but some fundamental characteristics of institutions suggest some clues.

1. Institutions are made up of formal rules, informal norms and the enforcement characteristics of both and it is the admixture of rules, norms, and enforcement characteristics that determines economic performance. While the formal rules can be changed overnight, the informal norms change only gradually. Since it is the norms that provide the essential "legitimacy" to any set of formal rules, revolutionary change is never as revolutionary as its supporters desire and performance will be different than anticipated. More than that societies that adopt the formal rules of another society (such as Latin American countries' adoption of constitutions like that of the United States) will have very different performance characteristics than the original country because both the informal norms and the enforcement characteristics will be different. The implication is that transferring the formal political and economic rules of successful western market economies to third world and eastern European economies is not a sufficient condition for good economic performance. Privatization is not a panacea for solving poor economic performance.

2. It is polities that shape economic performance because they define and enforce the economic rules of the game. Therefore the heart of development policy must be the creation of polities that will create and enforce efficient property rights. Unfortunately, however, research in the new political economy (the new institutional economics applied to polities) has been largely focused on the United States and other developed countries. While we know a lot about the characteristics of the polities of third world countries we have very little theory about such polities. We know even less about the consequences of radically altering the institutional framework of central and eastern European societies.

However, the characteristics of institutions described in the foregoing sections of this paper suggest some implications:

- Political institutions will be stable only if they are supported by organizations with an interest in their perpetuation. Therefore an essential part of political/ economic reform is the creation of such organizations.

- It is essential to change both the institutions and the belief systems for successful reform since it is the mental models of the actors that will shape choices. 
- Evolving norms of behaviour that will support and legitimize new rules is a lengthy process and in the absence of such reinforcing norms polities will tend to be unstable. - While economic growth can occur in the short run with autocratic regimes, long run economic growth entails the development of the rule of law and the protection of civil and political freedoms.

- Informal constraints-norms of behaviour, conventions, and codes of conduct-are a necessary (but not sufficient) condition for good economic performance. Societies with norms favourable to economic growth can sometimes prosper even with unstable or adverse political rules. The key is the degree to which there is enforcement of the adverse political rules. We know very little about the evolution of belief systems and consequent informal constraints although religions have clearly been a basic component of belief systems.

3. It is adaptive rather than allocative efficiency which should be the guide to policy. Allocative efficiency is a static concept with a given set of institutions; the key to continuing good economic performance is a flexible institutional matrix that will adjust in the context of evolving technological and demographic changes as well as shocks to the system. It is the creation of a stable polity with complementary norms that is the essential characteristic. Successful political/economic systems have evolved such characteristics over long periods of time. We know very little about how to create such systems in the short run or indeed, whether it is even possible to create them in short periods of time. However it is doubtful if the policies that will produce allocative efficiency are always the proper medicine for ailing economies. Efficient policies that are perceived to be inequitable will engender political reactions which can stall or reverse effective reforms. There is no greater challenge facing today's social scientist than the development of a dynamic theory of social change that will fill in many of the gaps in the foregoing analysis and give us an understanding of adaptive efficiency.

\section{Conclusions and future prospects of the scientific research}

The infrastructure of agrarian sphere as an object of research is complex, comprehensive and system identity that is in a state of development through constant change and improvement. During these changes architectonic infrastructure developing and improving the laws,are not known fully. Insufficient understanding of these laws not only due to the lack of deep scientific analysis of the process of formation and development of infrastructure, and proper scientific substantiation methodology of the process of learning it as an object.

The study of this process from the standpoint of institutional theory combined with approaches based on the laws of architectonics, let you discover new aspects of infrastructure as part of the entire socio-economic system that realizes its functions in agriculture and significant impaction the efficiency of the system. Therefore scientific research in this area is important both from positions of economic theory and application considerations.

\section{References}

Elinor Ostrom (2012). Managingshared. Theevolutionofinstitutions of collective action. - Kyiv. - P. 398.

Lopatynskyi, U.M. (2006). Institutionalization of transitive economy. Nauch. trudy DonNTU, 103-1. - Pp. 229-232. Wiliamson, O.E., Vinter, S.D. (2002). Nature of the Firm: Origins, Evolution and Development. Kyiv: A.S.K, 336 p. Pavlov, O.I., Khvesyk, M.A., Yurchyshyn, V.V. (2012). Sustainable development and security agro sector of Ukraine in the conditions of globalization challenges. Odesa, Astroprynt, $760 \mathrm{p}$.

Kostyrko, I.G. (2014). Gaps in institutional infrastructure and its evaluation: theoretical aspect. Kyiv, Ekonomika APK, № 2, pp. 81-86.

Kurylo, I. V. (2014). The content and value of some agricultural definitions. Kyiv, Ekonomy ACK, № 2, p. 87-92.

Berezivskyj, P.S. (2011). Organizational-economic mechanism of improving the socio-economic efficiency of agribusiness in Western Ukraine. Lviv, $688 \mathrm{p}$.

Ostashko, T.O. (2004) Market transformation of the agricultural sector. Kyiv, Feniks, 280 p.

Nosov, S.S. Infrastructure: the definition and specific features. [Electronic resource]. - Retrieved from: http:// uchebnikbesplatno.com/teoria ekonomicheskaya/ekonomicheskaya-teoria-nosova.html

Grytsenko, A.A. (2008). Institutional architectonic and dynamics of economic transformation. Kharkiv, Fort, 928 p.

\section{Иван КОРЧИНСКИЙ}

\section{МЕТОДОЛОГИЧЕСКИЕ АСПЕКТЫ ФОРМИРОВАНИЯ РАЦИОНАЛЬНОГО ДИЗАЙНА В ИНФРАСТРУКТУРЕ АГРАРНОГО СЕКТОРА УКРАИНЫ}

Аннотация. Целью работы является исследование методологических аспектов процесса формирования рациональной конструкции инфраструктуры аграрной сферы Украины на основе институционального подхода и законов архитектоники. Показано, что аграрная сфера Украины является сложной социально-экономической системой, формирование и развитие которой в процессе рыночных трансформаций происходит под институциональным влиянием. В статье рассмотрены факторы влияния на поведение хозяйствующих 
субъектов в условиях развития рыночной экономики. Особое внимание уделяется институциональным факторам экономического роста. Методика. Уточнено содержание понятий "аграрная сфера" и "инфраструктура" и их взаимной согласованности. Доказана целесообразность применения институционального подхода в органической совокупности с основными принципами архитектоники, что позволяет обосновать подход к созданию рациональной конструкции инфраструктуры аграрной сферы как одного целого на основе принципов структурирования, связи и взаимообусловленности ее элементов, исходя из основных законов архитектоники (закон равновесия, закон золотой середины и закон структуризации). В статье доказывается необходимость выбора теории институционализма как основной методологической базы при исследовании процесса инновационного развития экономической системы Украины. Определено, что неэффективная деятельность институтов в Украине является основной причиной низкого уровня внедрения инноваций, что негативно влияет на развитие экономики в целом. Результаты. Исследования показали новые аспекты функционирования инфраструктуры как части всей общественно-экономической системы, которая реализует свои функции в аграрной сфере и существенно влияет на эффективность функционирования этой системы. В целом процесс институализации отношений предполагает их формализацию и стандартизацию, иначе субъект общественной жизни не смог бы предсказать действия других субъектов, связанных с ним, и обеспечить их взаимодействие. Одной из специфических характеристик человеческого общества является именно сформированная институциональная система, которая регулирует поведение людей. В статье предпринята попытка комплексно классифицировать институты по разным организационными и функциональными признаками, предложенными авторитетными западными и отечественными учеными, а также рассмотреть принципы формирования различных институциональных категорий. Значение/оригинальность. Автором освещены подходы к трактовке эффективности институтов, а также проанализированы факторы, формирующие основные институциональные социально-экономические и политические различия. 